Schroeder, Kathleen. 2000. "Spatial Constraints on Women's Work in Tarija, Bolivia." Geographical Review 90(2): 191-205 (ISSN: 1931-0846) Permission to archive granted by publisher on 3/2/2010.

\title{
SPATIAL CONSTRAINTS ON WOMEN'S WORK IN TARIJA, BOLIVIA.
} Kathleen Schroeder

\begin{abstract}
This geography of women's work in the less-developed world is set in Tarija, Bolivia, a small city that has been dramatically changed by economic crisis and structuraladjustment programs. Explored is the spatial component of women's economic activities in a low-income barrio following the imposition of structural-adjustment programs in the 1980 s and 1990s. Women who pursue employment away from home must rely on other women. In particular, households that include more than one woman who is capable of handling important daily chores are more likely to have a woman engaged in incomegenerating activities away from the home and the neighborhood. Women at home make it possible for other women to extend their economic activity into the broader community. These findings are important because they draw attention to women's reliance on other women, how women use space, and how they are constrained by spatial factors as they negotiate their daily lives. Keywords: Bolivia, employment, structural adjustment, women.
\end{abstract}




\section{INTRODUCTION}

Two decades of debt crisis and economic recession have left Latin America vulnerable to the pressures of international lending agencies, transnational corporations, nongovernmental organizations (NGOS), and the U.S. government. This is particularly true in the low-income country of Bolivia (Figure 1), where "these actors have pressured Latin American governments into restructuring their economies and adopting neoliberal economic policies" (Halebsky and Harris 1995, 3). This process is often referred to as "structural adjustment." A vital component of structural adjustment, as prescribed by international lending institutions such as the World Bank, is marked divestment in the public sector. Cuts in programs that benefit the poor, such as subsidized food and health care, have been particularly controversial. There is a growing literature on the impact that structural adjustment is having on women in low-income countries (Due and Gladwin 1991; Geisler 1992; Tanski 1994; Sadasivam 1997), most of which concludes that women "have had to shoulder the heaviest burden of poverty and stress resulting from cutbacks in public expenditure" (Afshar and Dennis 1992, 4; Hays-Mitchell 1997). Nowhere is this truer than in Bolivia, among the poorest nations in Latin America and one that traditionally has had a large public sector (Horton 1992, 46).

Global economic restructuring routinely reaches straight into affected households; as a result, women are working longer hours inside and outside the home. In fact, women in most low-income households assume a triple role. According to Caroline Moser, they perform reproductive work (childbearing and rearing), productive work (at jobs inside and outside the home), and community work (by organizing and participating in a variety of meetings) (1992). To meet these demands, women rely on their extended families, in particular other women. Sylvia Chant points out that although women in Mexico have moved into male spheres, men have never moved into women's spheres $(1994,210)$. Therefore, additional pressure on the household implies increased strains on women. The paradox that women rely on other women to perform domestic duties is, of course, global and has occurred for centuries in the Andes (Zulawski 1990). Geographers are beginning a spatial analysis of this phenomenon in contemporary U.S. society (Mattingly 1999), but it remains too little studied abroad. This gap in the literature obfuscates women's varied and important economic roles. 


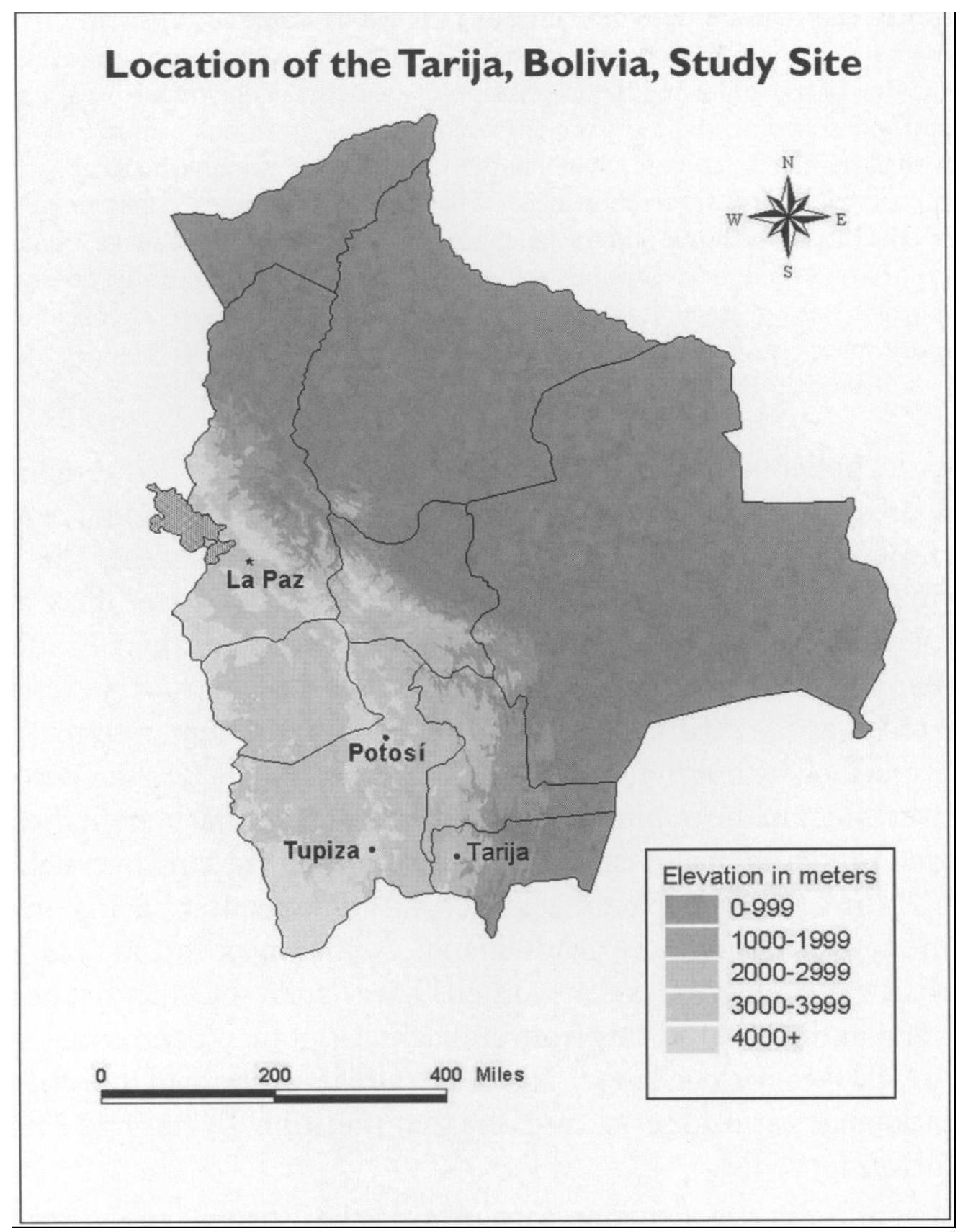

Fig. 1 - Bolivia. Source: USGS 1997. (Cartography by Breece Robertson, Appalachian State University)

Although social scientists are now trying to measure and study women's work, few employ a spatial perspective. An exception is Victoria Lawson, who has problematized the processes by which places of employment become gendered in Quito, Ecuador (1999). Maureen Hays-Mitchell has documented the spatiotemporal behavior of street vendors in Peru, but research on the spatial dimensions of all types of women's work 
(both paid and unpaid) in low-income countries remains otherwise scant (Hays-Mitchell 1994). An exception is Bimal Paul, who found that women in rural Bangladesh are increasingly seeking employment outside their homes (1992). These Muslim women are expanding their activity despite strong cultural taboos on women's presence in male space. Lack of attention to patterns of women's work in low-income countries is particularly surprising given the substantial research focus on gender and journey to work in industrialized countries. Women work significantly closer to home than do men, and therefore have smaller labor markets in spatial terms (a review of this literature is in Blumen 1994). As Susan Hanson and Geraldine Pratt make clear, small labor markets tend toward low-wage jobs, and low wages are linked with short commutes $(1995,104-$ 105). Some women choose jobs set close to home, accepting low wages as a necessary consequence. Other women are constrained by social and spatial factors, including a desire to be close to home to help fulfill child-care responsibilities, such as being nearby in case of emergency.

Susan Hanson and others argue that "the strategies women develop in leading their daily lives, particularly for combining home and paid employment, are embedded in, and actively shape, their local cultural and economic context" (1994,223). Little wonder, then, that just like their industrialized-world sisters, women in Bolivia must constantly balance competing demands of home, work, and community obligation and respond to these requirements in varied and creative ways. Unlike their comrades in the rich world, however, many of these women walk a tightrope without a social safety net to catch them if they stumble.

In this article I examine the implications of the economic crisis that hit Bolivia in the 1980s for household survival strategies. I then provide a case study from a peripheral barrio in Tarija, which demonstrates that certain household characteristics assist women in pursuing wage work away from their home or barrio. Women's participation in wage labor, particularly in economic activities away from their home or neighborhood (a measure of integration into the wider economy of the city if not of outright success), is strongly contingent on family structure. It concludes that women's employment is constrained spatially by their domestic responsibilities and suggests the wider use of government supported child-care facilities to help decrease the burden on families. 


\section{HOUSEHOLD STRATEGIES IN THE 1980S BOLIVIAN ECONOMIC CRISIS}

During the late 1970s and 1980s Bolivia suffered a debt crisis, political instability, hyperinflation, and the collapse of the world tin market. The structural-adjustment measures imposed to put Bolivia "back on track" involved substantial relocation of production and labor migration. In general, structural adjustment is attempted by implementing trade reform, currency devaluation, fiscal and public-sector reform, and control of inflation and debt (World Bank 1989). Of course, Bolivia was only one of the Latin American countries undergoing structural adjustment during this era: Argentina, Peru, Ecuador, and other nations have experienced similar social and economic transformations since the late 1970s (Moser 1989, 1992; Palermo 1990; Glewwe 1992; Smith, Acuna, and Gamarra 1994).

In Bolivia, the economic crisis prompted the newly elected government of Victor Paz Estenssoro to effect policies aimed at stabilization and structural adjustment called the "New Economic Policy" (NEP) in 1985. Exchange rate stabilization aspects of the policy--notably a linking of the Bolivian currency to the U.S. dollar--were immediately successful, and inflation fell soon after implementation (Sachs 1987). A separate component of the structural-adjustment policies was aimed at curtailing government expenditures, especially mining. As tin mines were closed, population drained from the mining regions to coca-growing areas and valley cities (Labrousse 1990; Schroeder 1995).

Structural-adjustment programs controlled inflation, but their success in increasing economic growth was less stirring. Average annual growth rates in Bolivia from 1990 to 1997 were 3.8 percent (World Bank 1998). Manuel Pastor suggests that part of the NEP was designed to disempower the labor movement and in that, to make the country more attractive to investors $(1992,90)$. This strategy appears to be working. Since the 1997 election of former dictator (1971-1978) Hugo Banzer Suarez, the business climate in Bolivia has remained favorable, thanks to his government's avowal of strong neoliberalism and an aggressive pro-foreign investment orientation (Hinchberger 1997).

Most multilateral agencies, such as the World Bank and the International Monetary Fund, now acknowledge that structural adjustment hurts the poor (Whitehead 1995). In Bolivia, the poorest sectors of society are enduring a crisis exacerbated by the neoliberal reforms, a crisis so great that in 1985 the World Bank established funds to provide a cushion for the poor, and in doing so acknowledged the social costs of its 
policies (Graham 1992). The task of the World Bank's Emergency Social Fund (ESF) was to provide a measure of protection for the poor from the adverse effects of the economic crisis and World Bank-imposed structural-adjustment programs. The ESF included a separate compensation program to provide temporary employment for those who had lost their jobs.

Structural adjustment and ESFS are nonetheless criticized for failing to meet the needs of the poorest and most at risk populations (Beneria and Mendoza 1995). In particular, women's poverty remains hidden from development planners, and critics argue that the Bank fails to address issues of gender in its literature and policies (Wood 1998). And so, as economic restructuring loads additional stress on the household, families are left to react in creative ways. In simplest form, households in Latin America respond to crisis by engaging in strategies that minimize expenditures and generate income (Chant 1994). Expenditure-minimizing strategies can include lowering consumption of health care, transportation, education, housing, and other goods. For example, children are taken out of school to save money on matriculation, transportation, clothes, and other expenses (Moser 1992). Lourdes Beneria noted that middle-and low-income women in Mexico City were spending more time shopping for cheaper foodstuffs (1991); Mercedes Gonzalez de la Rocha found that low-income households in Guadalajara, Mexico, protected diet and food consumption by sacrificing home improvements and formal medical care and by producing in the home items they previously purchased in the market (1991).

Income-generating strategies are equally diverse. Few households rely on a single wage earner employed in a single occupation. A household may include several people who engage in a strategy of multiple livelihoods (Weil 1995). Many studies fail to capture the complexity of household strategies because they miss the variety of small, often labor-intensive jobs that families engage in at home, such as taking in laundry or having a small store in the front room. A woman may work as a maid in the morning and sell pastries in the afternoon. A man may take a construction job when one is available and help a relative who repairs truck engines on other days. This doubling- or tripling-up of jobs may not feature in ordinary employment reporting.

Households take on complex spatial and temporal divisions of labor. For example, in southern Bolivia many households have members who migrate seasonally to Argentina for agricultural labor, remaining there for months at a time (Whiteford 1981). Households in a squatter settlement in Tarija periodically send women to weeklong 
fiestas, where they sell food and handicrafts (Schroeder 1998). These strategies figure prominently in household decision making concerning income generation.

Underlying, at least for women, issues of income generation is also an abiding concern for domestic responsibilities. By some estimates, less-skilled women work an average of sixty hours per week on income-generating activities, and low-income women have traditionally worked twelve- to eighteen-hour days to meet their multiple responsibilities (Moser 1992, 106, 112). When women realize that they simply have no more time, additional demands are shifted to other female members of the household. Chant $(1991,93)$ and Moser (1992) have found that women in "male-headed" households undertake paid work because a female coresident is willing and able to take on domestic chores. However, the spatial component of these income-generating activities remains too little explored.

\section{TARIJA, BOLIVIA, IN THE 1990s}

Examination of the economic strategies and spatial arrangements of households in a low-income neighborhood in Tarija, Bolivia, reveals the spatial dimensions of division of labor. Tarija, capital of Bolivia's southernmost state, hosted a substantial inmigration of former miners during the 1980s (Schroeder 1995). A colonial-era city with a population of about 100,000 in the early 1990 s, Tarija is set in a river valley at an elevation of 2,000 meters and is nationally known for its moderate climate and relaxed pace of life (INE 1993).

Francisco Toledo, viceroy of Peru, founded Tarija in 1574 to encourage Spanish settlement in the region then known as Upper Peru. Mid-elevation cities such as Tarija and Cochabamba, founded a few years earlier, were important during the colonial era because they provided access to, and control over, a large indigenous population and different ecological and economic zones. Tarija became known as a center of grain and wine production.

Bolivia is famous for its mineral wealth, and its economic crisis in the 1980s was, in a sense, a crisis of the state-owned mines. Because of falling commodity prices and losses in the government-owned tin mines, the Corporacion Minera de Bolivia (COMIBOL) was specifically targeted for reform. Between 1985 and 1987 COMIBOL'S labor force was reduced by more than 75 percent (Pastor 1991, 225). Unemployed 
miners left Bolivia's highland regions, searching for a new way of life. As a result, Tarija --and nearly every other city in the country--received a large influx of miners. The lowland city of Santa Cruz probably received the greatest numbers of migrants overall, and many former miners in the eastern portion of the country reestablished themselves in illicit coca production (Labrousse 1990).

The exact number of former miners who moved to Tarija is unknown. However, this small city received more than 4,500 new arrivals from states with strong mining orientations in the five-year period just prior to the 1992 national census (INE 1993, 133-134). Former miners living in the city of Tarija reported to me that they enjoy the more moderate climate and find the city an agreeable place in which to make a new life for themselves.

Women who had relocated from the mining region told me many stories about their lives before coming to Tarija. Most of them were married to men who had worked for the government-owned mining cooperative, in jobs ranging from accountant to mechanic to miner. They all agreed that working inside the mines was difficult and dangerous, and few showed any regrets at having left that life behind. When I asked them about their own economic opportunities in the mining region, the women had a variety of responses. Some said they did not work outside the home because their husbands earned enough money to support the family. They commented that they frequently spent a great deal of time waiting in line to receive subsidized food and supplies from the government-owned store. Some women did work outside the home. One of the few places where women could find employment was on the slag heaps. This re-sorting job consisted of gathering rocks with mineral content that would otherwise be discarded.

Almost universal among relocated miners and their families was agreement that for people who had been able to find new employment, life was better following relocation. Finding a reliable job, however, could prove difficult. Former miners and mining families employed various creative economic strategies. Yet the foremost concern in these strategies was a spatial component; that is, the ability of households to balance the demands of income generation (which implies wage labor away from the home) with the needs of household reproduction (most of which must be done in the home). Because much of the readily accessible employment in Tarija is available only to women (as a nanny or a maid, for example), tension between work away from home and in the home has affected nearly all former miners' households. 
The study site detailed here is a barrio known as Lourdes, founded in 1987 on the northern margin of Tarija to house unemployed miners from the highlands. Many of its residents came from mines around Tupiza, a small mining city in southeastern Potosi State, 230 kilometers west of Tarija. When the government tin mines closed, many of the former employees received a severance package of as much as U.S. $\$ 500$. In many cases the miners used the money to relocate and build communities such as Lourdes. Some former miners received help with their move and/or resettlement from NGOS or government agencies. Lourdes itself has received substantial contributions from the Christian Children's Fund. As a planned community for the displaced mining population, the barrio is relatively well equipped with running water, electricity, a medical clinic, and public transportation.

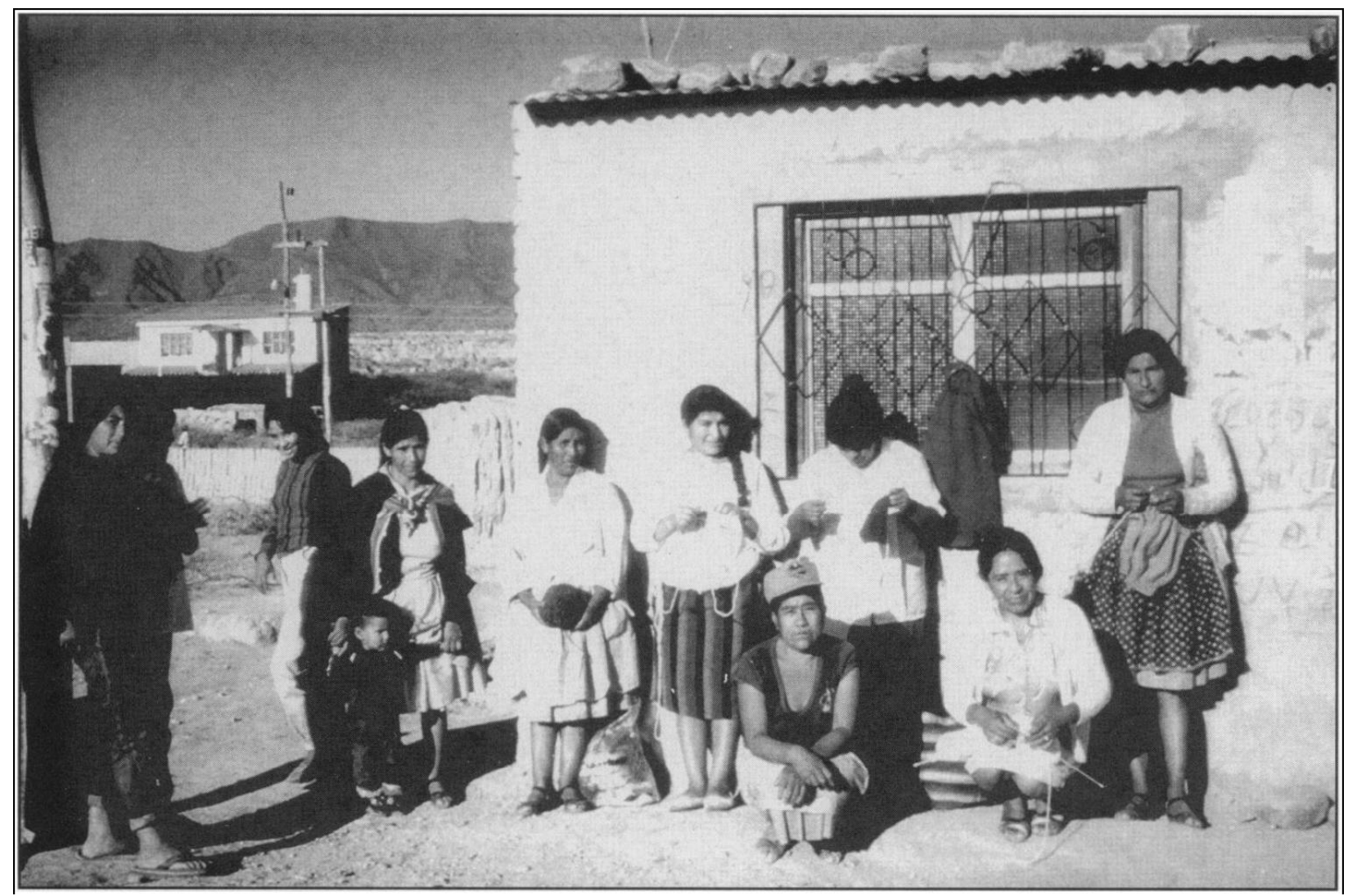

Fig. 2-Meeting of the mothers' club in Lourdes, Tarija, Bolivia, November 1993. (Photograph by the author)

Lourdes also has an extensive social infrastructure. NGOs and government agencies have helped shape the social space of the barrio by providing services such as lowcost medical care and schools. Facilities such as a mothers' club, where women gather once 
a week to master new skills, provide excellent arenas for women to strengthen their social connections (Figure 2). Community buildings constructed with funds from NGOS and government agencies are clustered around a central square--not quite a plaza-where people congregate before and after meetings. Children gather and play on a cement basketball court in the center of the barrio while their mothers are occupied with various activities.

The children of the former miners have good access to schools. A primary school is in the barrio, and a vocational high school, funded in part by donations from the Canadian government, is at its edge. Several barrio families send their children to this high school. The benefits of having neighborhood schools are sometimes overlooked by outsiders-but not by the barrio families. Parents strongly prefer to have their children's school nearby, so they do not have to pay for public transportation or spend time walking young children to school themselves. Moreover, schools create a moderately profitable but, most important, spatially desirable location for barrio women to work in as vendors. One Lourdes mother, for example, has a particularly favorable spatial arrangement for income generation. With her infant securely tied to her back, she accompanies her older children to the barrio's primary school, where she sells candies before classes start. Once the children are in class, she may make a quick trip to the market before returning home to start preparing the traditional midday meal. When classes are about to let out she walks back to the school to sell candy and wait for her children. Other women in Lourdes are vendors at the nearby high school. Barrio women carefully exploit these microniches of economic opportunity because they fit fairly easily into the other spatial demands of their day.

The demands on barrio women's time are both substantial and greatly influenced by simple distance. Not only must women meet a wide range of obligations, they must walk almost everywhere they need to go. Even in a relatively compact city such as Tarija, the distance from Lourdes to downtown is almost 1.5 kilometers, and the distance from the barrio to the main market is comparable. Daily trips to the market, often toting small children and groceries, can consume a woman's day as well as her energy.

Bolivian women are accustomed to these conditions, of course, and many would never mention the time and energy they spend walking everywhere. However, time and space are part of their everyday realities, and when the women are pressed about why they have been unable to complete certain tasks, they will often state very plainly that they are too tired or too busy with other things. Bolivian women are indeed busy, and their 
days can be long and exhausting. Given these conditions, how do women manage to work outside their homes and barrios?

\section{SPATIAL ARRANGEMENTS AND HOUSEHOLD STRATEGIES}

The spatial and household arrangements that women use in order to engage in incomegenerating activities vary, but a key factor is household composition itself. The household is the key unit of analysis; that said, even defining a household presents certain challenges. Households are dynamic and complex; their composition changes depending on a variety of factors, including economic opportunities and the group's particular interpersonal relationships. A series of interviews conducted over a one-year period--1993--captures some of this complexity and further refines definitions of households.

The population $(n=298)$ included in this study is young: More than 41 percent are under the age of fifteen. Households $(n=44)$ average seven people and are typically made up of extended families, which commonly include a younger sister or brother of the husband or the wife. In a country where life expectancy at birth is still under sixty, this arrangement is more likely than is having elderly grandparents present in the household--at least in Lourdes.

Connie Weil found differences in household composition useful for explaining differential economic success among agricultural colonists in the Bolivian Chapare (1989). As household demographics change, as children are added or mature and leave the home, agricultural strategies change. Weil suggested a possible relationship between the number of places where a household owns property (a measure of economic success) and the number of males in a household over the age of fifteen-those people who do the most agricultural work $(1989,284)$.

Given Weil's findings, I examined household composition in Lourdes in an attempt to explain access to a wider variety of economic opportunities (a surrogate measure of success) (Table I). I compared households in which at least one woman (a female fifteen years of age or older) works outside the barrio with those in which no woman works outside the barrio by testing (using the Student's t-test) for differences in household size and in number of children per household, adults per household, and children per adult. 
The results reveal an intriguing picture. There is a statistically significant $(p=0.03)$ difference between the size of households in which at least one woman works outside the barrio and those in which no woman works outside the barrio. Households in which women work outside the barrio are larger. However, there is virtually no difference in the number of children per household. The number of children does not seem to have much of an impact on the location of women's employment. The number of adults per household is a significant $(p=0.003)$ difference, and so is the number of children per adult $(p=0.001)$. This indicates that having a number of adults present in the household makes it more likely that a woman will work outside the barrio. These household relationships almost certainly are not due to chance but instead show a clear strategy whereby women rely on the labor of other women to facilitate income-generating activities away from the barrio.

\section{HOUSEHOLDS WITH AT LEAST ONE WOMAN WORKING OUTSIDE THE BARRIO}

In Lourdes, eighteen of the forty-four households include at least one woman who engages in income-generating activities outside the barrio (Table II). Of these eighteen families, fourteen have another woman who stays home to take care of household responsibilities. A fairly successful household of this type is that of Gueramina. She is forty-five years old and works in downtown Tarija at a store that sells cloth. Her husband works for the municipal government. They are relocated tin miners from the Tupiza area. They share a house with an adult daughter, her husband, and their infant daughter. Three of Gueramina's other children also live with them. The adult daughter assumes many of the household responsibilities while her mother is at work. The women are pleased with their arrangement, and a certain fluidity of responsibilities seems to occur naturally. For example, on her day off Gueramina contributes fully to the running of the household and caring for her granddaughter. She proudly brings her to the medical clinic for examinations and to mothers' club meetings. She reports that she relies on her daughter for her innumerable contributions to the smooth running of the household. In fact, this arrangement makes so much sense to the family that it is difficult for them to imagine how women work outside the barrio without other female labor in the house. 
Table I-Households in Tarija, Bolivia, with at Least One Adult Woman Member ${ }^{a}$

\begin{tabular}{|c|c|c|c|c|c|}
\hline $\begin{array}{l}\text { DOES AT LEAST ONE } \\
\text { ADULT WOMAN WORK } \\
\text { OUTSIDE THE BARRIO? }\end{array}$ & $\begin{array}{c}\text { NUMBER } \\
\text { OF } \\
\text { HOUSEHOLDS }\end{array}$ & $\begin{array}{c}\text { SIZE } \\
\text { OF } \\
\text { HOUSEHOLD }\end{array}$ & $\begin{array}{l}\text { CHILDREN } \\
\text { PER } \\
\text { HOUSEHOLD }\end{array}$ & $\begin{array}{c}\text { ADULTS } \\
\text { PER } \\
\text { HOUSEHOLD }\end{array}$ & $\begin{array}{l}\text { CHILDREN } \\
\text { PER } \\
\text { ADULT }\end{array}$ \\
\hline Yes & 18 & 8.0 & 2.7 & 5.3 & .54 \\
\hline \multirow[t]{2}{*}{ No } & 26 & 5.9 & 2.9 & 3.1 & 1.2 \\
\hline & & $p=0.03$ & $p=0.8$ & $p=0.003$ & $p=0.001$ \\
\hline
\end{tabular}

${ }^{a}$ Adult women are defined as those who are fifteen years of age or older. Children per household and adults per household do not equal household size due to rounding.

Table II-Effect of the Number of Adult Women in a Household on the LOCATION OF WORK, TARIJA, BOLIVIA ${ }^{a}$

\begin{tabular}{cccc}
\hline $\begin{array}{c}\text { DOES AT LEAST ONE } \\
\text { ADULT WOMAN } \\
\text { WORK OUTSIDE } \\
\text { THE BARRIO? }\end{array}$ & $\begin{array}{c}\text { TOTAL } \\
\text { NUMBER } \\
\text { OF } \\
\text { HOUSEHOLDS }\end{array}$ & $\begin{array}{c}\text { NUMBER OF } \\
\text { HOUSEHOLDS } \\
\text { WITH ONE } \\
\text { ADULT WOMAN }\end{array}$ & $\begin{array}{c}\text { NUMBER OF } \\
\text { HOUSEHOLDS WITH } \\
\text { MORE THAN ONE } \\
\text { ADULT WOMAN }\end{array}$ \\
\hline Yes & 18 & 4 & 14 \\
No & 26 & 17 & 9 \\
& & $\mathrm{p}=0.007$ Fisher Exact Test \\
\hline
\end{tabular}

${ }^{a}$ Adult women are defined as those who are fifteen years of age or older.

In four households a woman works away from the barrio without another adult woman to take over her domestic responsibilities. These are interesting cases and deserve further examination. One of these households, that of Olympia and her husband, does not have any children yet. If children come, Olympia says that her family will probably move in with her in-laws so that she can keep working outside the barrio.

Another household includes no children under the age often. At a young age the children in Hortenica's household learned to help out. Even though her thirteen-year-old daughter is not considered an adult for this study, she has all the responsibility of one. Her mother proudly explains that her daughter can do laundry and cook. This girl is fulfilling adult responsibilities by maintaining the home so her mother can earn extra money working as a maid. The irony of this situation is not lost on this family: Hortenica refers to her daughter half jokingly as her empleada (maid). 
Flora's "female-headed" household falls into the same category. Flora has three children, aged seven, nine, and eleven. The eleven-year-old daughter assumes many of her mother's domestic responsibilities while attempting to supervise her younger siblings. Neighbors report that things are not going very well in this household, and they believe that the children are not properly fed or cared for. Even in Bolivia, it seems, people are concerned about a young girl having to shoulder too much adult responsibility.

A situation like Flora's draws attention to the need for institutional support for working women. The provision of formal day care is increasing in Bolivia as more women work outside the home. Interestingly, the World Bank has become an important source of funds for day-care programs in Tarija, part of the network of daycare centers it supports throughout cities in Bolivia. Child care at these centers is available at low cost, and centers at times accept payment in foodstuffs rather than cash. Centers have local and national oversight and attempt to provide an intellectually stimulating environment and nutritious lunches for the children in their care. The centers are staffed primarily by neighborhood women, providing further childcare and employment opportunities in poor areas. Through this program the World Bank is attempting to ameliorate the impact of its structural-adjustment policies on poor urban women. The young children in the fourth household in this study that has a woman working outside the barrio without another adult woman at home go to a World Bank-supported day-care center.

\section{HOUSEHOLDS WITHOUT A WOMAN WORKING OUTSIDE THE BARRIO}

In seventeen of the twenty-six households in which no adult woman works outside the barrio, only one adult woman is present in the household. A good example of such a household is that of Teresa. She and her husband are in their late thirties. They have three school-aged children, and they operate a small bakery at home. Bread from their bakery is sold in the barrio, and, with additional income from her husband's occasional agricultural labor, they manage to make ends meet. Teresa would eventually like to expand her business and start selling bread to a wider market. However, until her children are better able to take care of themselves, or perhaps her sister-in-law moves in, she will keep her business home based.

Are there households with two or more adult women in which no woman works outside the barrio? Yes, and these nine households provide a clearer picture of the complexity of economic arrangements. In two households, one of the two adult women is elderly, in 
poor health, and in need of considerable care. In one case Lucia, a woman in her thirties, is responsible for her elderly mother-in-law and three school-aged children. The family operates a small store out of the front room of the house to supplement the income of her husband, who works for the municipal government.

In three households in this study, the "other adult female" is enrolled in school rather than working. In each case these are younger women--all between the ages of fifteen and eighteen--who have decided, with the support of their families, to continue their education. These women plan to make a substantial financial contribution to their households in the future.

In three other households the women run small home-based stores. These tiendas have a very small profit margin and require the almost constant attention of family members to function. It is common for people to buy a single box of matches, one cigarette, or a bottle of soda from these stores--transactions that net little profit for the shopkeepers. However, tiendas play more than an economic role in the community: They also serve as important gathering places. Often a store will have a bench outside where people sit and exchange news. Shopkeepers are regular conduits for barrio information. The last of the nine households with two adult women who work in the barrio runs one of the World Bank-sponsored day-care centers within the home.

These data support a conclusion that extended families are utilized as a survival strategy to help women work outside the barrio. Such family structures increase the range of possible household arrangements and facilitate a woman's employment away from home. They also provide opportunities to pursue other goals, such as higher education. Of course, this does not prove that women who work outside the home and barrio are better off financially than are women who do not. No data were collected on income at the household level because families were reluctant to discuss such issues. However, women themselves seem to believe that they are better off if they have a job outside the home and are willing to endure both demanding schedules and sometimes harsh treatment by employers in order to keep their job. Households with a woman working outside the barrio appear better able to provide for the basic needs of their members. 
For women working outside the barrio, the most common occupation is that of maid. Most other women work at similar service-related jobs, such as cooking in a soup kitchen, cleaning the city hospital, or sweeping city streets. A few women work in factories--in particular a poultry-processing plant near Lourdes. Although the jobs are not glamorous, the earnings that employment provides are perceived as a vital part of the economy of household and barrio. Male wage earners are, for the most part, aware of their spouse's income-generating activities and supportive of their efforts, even if this means that they end up doing some domestic tasks.

In a total of twenty-six households, 59 percent of the households included in the study, no woman presently works outside the barrio. However, that is not to say that these women do not work. They engage in a variety of income-generating activities that take place at home or in the barrio: running a small store, selling candies at the barrio school, taking in laundry. Clearly, no household is going to become rich from these activities, but with their already impressive list of responsibilities, it is unlikely that women will take on additional chores if the money they make is not needed.

\section{CONCLUSIONS}

This study indicates that the spatial arrangement of women's work can be contingent on family structure and raises questions about the survival strategies of low-income women. Participation in wage labor outside the barrio, an important economic opportunity--according to members of the barrio--is affected by family composition and, importantly, by the ability of women to rely on the labor of other women. Of course, a study of forty-four households of relocated tin miners is not readily generalizable to all households in Bolivia. For example, in a nearby squatter settlement, composed primarily of former and present agricultural workers, the spatial arrangement of women's economic activities is substantially different. Households divide their time between rural agricultural holdings and urban residences (Schroeder 1998). However, it is possible to make some general observations and recommendations.

For women who have help, jobs outside the barrio provide an alternative to the limited opportunities of barrio employment. Providing assistance in the form of communitybased day-care facilities may substantially increase opportunities for female employment and has become a key initiative of the World Bank in Bolivia. By 
acknowledging--at least implicitly--that structural adjustment has increased the burden on women, the World Bank is taking steps to help families cope. This program may signal a deeper level of understanding by the Bank of the impact of its structuraladjustment programs. The provision of low-cost, high-quality community-based day care should increasingly attract the attention of development planners. Studying the impact of this program in Tarija could contribute to its successful implementation in other cities.

For women who lack the help of other female family members, working close to home makes it feasible to coordinate income-generating activities with unpaid domestic labor and to fulfill multiple obligations within the household. These women are an invaluable asset to the barrio. They are the ones repeatedly asked to participate in various community-development projects. However, development planners must be wary of increasing demands on this sector of the population. The time and energies of these women can also be stretched too thin, ensuring the failure of certain otherwise sound projects.

Almost every household has a woman engaged in income-producing activity. Women indicate that they are well aware of the economic opportunities available to them close to home and that gaining access to these opportunities is an important consideration. Many of the mothers' club activities, for example, focus on income generation for women who cannot take jobs away from the home. Women are keenly interested in income-generating ideas. However, they grow weary when projects do not reasonably mesh with their existing obligations.

A growing body of literature reveals that we have much to learn about the complexity of the spatial arrangements of women's activities. Citizens of economically advanced countries are not the only ones faced with constraints of time and space. Too often we assume that people in low-income countries enjoy a "slower pace of life"; plans to help these economies develop often ignore the spatial arrangements, in particular the interconnections between the locations of housing, employment, and child-care providers, that are crucial to the daily lives of all people. As structural-adjustment programs proliferate around the globe it is vital to draw attention to the spatial reality of women's lives. 


\section{REFERENCES}

Afshar, H., and C. Dennis. 1992. Women, Recession and Adjustment in the Third World: Some Introductory Remarks. In Women and Adjustment Policies in the Third World, edited by H. Afshar and C. Dennis, 3-12. New York: St. Martin's Press.

Beneria, L. 1991. Structural Adjustment, the Labour Market and the Household: The Case of Mexico. In Towards Social Adjustment: Labour Market Issues in Structural Adjustment, edited by G. Standing and V. Tomkin, 161-183. Geneva: International Labour Organization.

Beneria, L., and B. Mendoza. 1995. Structural Adjustment and Social Emergency Funds: The Cases of Honduras, Mexico and Nicaragua. European Journal of Development Research 7 (1): 53-76.

Blumen, O. 1994. Gender Differences in Journey to Work. Urban Geography 15 (3): 223-245.

Chant, S. H. 1991. Women and Survival in Mexican Cities: Perspectives on Gender, Labour Markets, and Low-Income Households. Manchester, England, and New York: Manchester University Press.

----. 1994. Women, Work and Household Survival Strategies in Mexico, 1982-1992: Past Trends, Current Tendencies and Future Research. Bulletin of Latin American Research 13 (2): 203-233.

Due, J. M., and C. H. Gladwin. 1991. Impacts of Structural Adjustment Programs on African Women Farmers and Female-Headed Households. American Journal of Agricultural Economics 73 (5): 1431-1439.

Geisler, G. 1992. Who Is Losing Out? Structural Adjustment, Gender, and the Agricultural Sector in Zambia. Journal of Modern African Studies 30 (1): 113-139. 
Glewwe, P. 1992. Poverty and Inequality during Unorthodox Adjustment: The Case of Peru, 1985-1990. Washington, D.C.: World Bank.

Gonzalez de la Rocha, M. 1991. Family Well-Being, Food Consumption and Survival Strategies during Mexico's Economic Crisis. In Social Responses to Mexico's Economic Crisis of the 1980s, edited by M. Gonzalez de la Rocha and A. Escobar Latapi, 115127. San Diego: University of California, San Diego, Center for U.S.-Mexican Studies.

Graham, C. 1992. The Politics of Protecting the Poor during Adjustment: Bolivia's Emergency Social Fund. World Development 20 (9): 1233-1251.

Halebsky, S., and R. L. Harris. 1995. Introduction: Capital, Power, and Inequality in Latin America. In Capital, Power, and Inequality in Latin America, edited by S. Halebsky and R. L. Harris, 1-19. Boulder, Colo.: Westview Press.

Hanson, S., and G. Pratt. 1995. Gender, Work, and Space. London and New York: Routledge.

Hanson, S., G. Pratt, D. Mattingly, and M. Gilbert. 1994. Women, Work, and Metropolitan Environments. In Women and the Environment, edited by I. Altman and A. Churchman, 227-253. New York: Plenum Press.

Hays-Mitchell, M. 1994. Streetvending in Peruvian Cities: The Spatio-Temporal Behavior of Ambulantes. Professional Geographer 46 (4): 425-438.

----- 1997. Development vs. Empowerment: The Gendered Legacy of Economic Restructuring. Conference of Latin Americanist Geographers Yearbook 23: 119-131. 
Hinchberger, B. 1997. Bolivia Embraces "Capitalism." Institutional Investor, March, 179181.

Horton, S. 1992. Labour Markets and the Shock Treatments in Bolivia. Canadian Journal of Latin American and Caribbean Studies 17 (33): 45-71.

INE [Instituto Nacional de Estadistica]. 1993. Bolivia: Censo nacional de poblacion y vivienda 1992. Vol. 6, Tarija: Resultados finales. La Paz: Instituto Nacional de Estadistica.

Labrousse, A. 1990. Dependence on Drugs: Unemployment, Migration, and an Alternative Path to Development in Bolivia. International Labour Review 129 (3): 333348.

Lawson, V. 1999. Tailoring Is a Profession, Seamstressing Is Work! Revisiting Work and Reworking Gender Identities among Artisanal Garment Workers in Quito, Ecuador. Environment and Planning (A) 31 (2): 209-227.

Mattingly, D. 1999. Job Search, Social Networks, and Local Labor-Market Dynamics: The Case of Paid Household Work in San Diego, California. Urban Geography 20 (1): 46-74.

Moser, C. O. N. 1989. The Impact of Recession and Structural Adjustment on Women: Ecuador. Development 31 (1): 75-83.

----. 1992. Adjustment from Below: Low-Income Women, Time and the Triple Role in Guayaquil, Ecuador. In Women and Adjustment Policies in the Third World, edited by $\mathrm{H}$. Afshar and C. Dennis, 87-116. New York: St. Martin's Press. 
Palermo, V. 1990. Programas de ajuste y estrategias politicas: Las experiencias recientes de la Argentina y Bolivia. Desarrollo Economico 30 (119): 333-366.

Pastor, M., Jr. 1991. Bolivia: Hyperinflation, Stabilisation, and Beyond. Journal of Development Studies 27 (2): 211-237.

----. 1992. Inflation, Stabilization, and Debt: Macroeconomic Experiments in Peru and Bolivia. Boulder, Colo.: Westview Press.

Paul, B. K. 1992. Female Activity Space in Rural Bangladesh. Geographical Review 82 (1): 1-12.

Sachs, J. 1987. The Bolivian Hyperinflation and Stabilization. American Economic Review 77 (3): 279-283.

Sadasivam, B. 1997. The Impact of Structural Adjustment on Women: A Governance and Human Rights Agenda. Human Rights Quarterly 19 (3): 630-665.

Schroeder, K. 1995. Living on the Edge: A Comparison of Two Marginal Barrios in Tarija, Bolivia. Ph.D. diss., University of Minnesota.

----. 1998. Urban Squatters as Agricultural Migrants: The Case of Tarija, Bolivia. South Eastern Latin Americanist 41 (4): 33-43.

Smith, W. C., C. H. Acuna, and E. A. Gamarra, eds. 1994. Democracy, Markets, and Structural Reform in Latin America: Argentina, Bolivia, Brazil, Chile, and Mexico. New Brunswick, N.J.: Transaction Publishers. 
Tanski, J. 1994. The Impact of Crisis, Stabilization and Structural Adjustment on Women in Lima, Peru. World Development 22 (11): 1627-1642.

USGS [U.S. Geological Survey]. 1997. Global 30-Arc-Second Elevation Data Set. Sioux Falls, S.D.: EROS Data Center.

Weil, C. 1989. Differential Economic Success among Spontaneous Agricultural Colonists in the Chapare, Bolivia. In The Human Ecology of Tropical Land Settlement in Latin America, edited by D. A. Schumann and W. L. Partridge, 264-297. Boulder, Colo.: Westview Press.

Weil, J., ed. 1995. "Multiple Livelihoods" in Contemporary Societies: Ethnographic Sketches of Individuals, Households, and Communities. Special issue of Anthropology of Work Review 16 (1-2).

Whiteford, S. 1981. Workers from the North: Plantations, Bolivian Labor and the City in Northwest Argentina. Austin: University of Texas Press.

Whitehead, C. 1995. Emergency Social Funds: The Experience of Bolivia and Peru. Development in Practice 5 (1): 53-57.

Wood, C. 1998. "Not Sufficiently Important": Gender and Structural Adjustment at the World Bank. Paper presented at the International Congress of Latin American Studies, Chicago, 24-26 September.

World Bank. 1989. World Development Report 1989. New York: Oxford University Press.

----. 1998. World Development Report 1998. New York: Oxford University Press.

Zulawski, A. 1990. Social Differentiation, Gender, and Ethnicity: Urban Indian Women in Colonial Bolivia, 1640-1725. Latin American Research Review 25 (2): 93-113. 